\title{
Influence of sulfur in fuel on the properties of diffusion flame soot
}

\author{
Yan Zhao ${ }^{\text {a, b }}$, Qingxin Ma ${ }^{\text {a, b }}$, Yongchun Liu ${ }^{\text {a, b, c }}$, Hong He ${ }^{\text {a, b, c,* }}$ \\ ${ }^{a}$ State Key Joint Laboratory of Environment Simulation and Pollution Control, Research Center for Eco-Environmental Sciences, Chinese Academy of \\ Sciences, Beijing 100085, China \\ ${ }^{\mathrm{b}}$ College of Resources and Environment, University of Chinese Academy of Sciences, Beijing 100049, China \\ c Center for Excellence in Urban Atmospheric Environment, Institute of Urban Environment, Chinese Academy of Sciences, Xiamen 361021, China
}

\section{H I G H L I G H T S}

- Lean flame soot was influenced more by sulfur in fuel than rich flame soot.

- Sulfate species were mainly formed on the surface of soot.

- The diameter of primary lean flame soot from high sulfur content fuel increased.

- The hygroscopicity of lean flame soot from high sulfur content fuel increased.

\section{A R T I C L E I N F O}

\section{Article history:}

Received 4 November 2015

Received in revised form 28 July 2016

Accepted 1 August 2016

Available online 2 August 2016

\section{Keywords:}

Sulfur-containing fuel

Sulfate species

Alkynes

Primary particle size

Number concentration

Hygroscopicity

\begin{abstract}
A B S T R A C T
Previous studies indicate that sulfur in fuel affects the hygroscopicity of soot. However, the issue of the effect of sulfur in fuel on soot properties is not fully understood. Here, the properties of soot prepared from fuel with a variable sulfur content were investigated under lean and rich flame conditions. Lean flame soot was influenced more by sulfur in fuel than rich flame soot. The majority of sulfur in fuel in lean flame was converted to gaseous $\mathrm{SO}_{2}$, while a small fraction appeared as sulfate and bisulfate (referred to as sulfate species) in soot. As the sulfur content in fuel increased, sulfate species in lean flame soot increased nonlinearly, while sulfate species on the surface of lean flame soot increased linearly. The hygroscopicity of lean flame soot from sulfur-containing fuel was enhanced mainly due to sulfate species. Meanwhile, more alkynes were formed in lean flame. The diameter of primary lean flame soot particles increased and accumulation mode particle number concentrations of lean flame soot from sulfurcontaining fuel increased as a result of more alkynes. Because the potential effects of soot particles on air pollution development greatly depend on the soot properties, which are related to both chemical aging and combustion conditions, this work will aid in understanding the impacts of soot on air quality and climate.
\end{abstract}

() 2016 Elsevier Ltd. All rights reserved.

\section{Introduction}

Soot particles, which are produced from incomplete combustion of fossil fuels and biomass, are ubiquitous in the atmosphere and comprise $10-50 \%$ of the total tropospheric particulate matter (Jacobson, 2001; Lary et al., 1999). They have an important influence on global and regional radiative balance and climate by directly absorbing solar radiation as well as by indirectly scattering

\footnotetext{
* Corresponding author. State Key Joint Laboratory of Environment Simulation and Pollution Control, Research Center for Eco-Environmental Sciences, Chinese Academy of Sciences, Beijing 100085, China.

E-mail address: honghe@rcees.ac.cn (H. He).
}

solar radiation as cloud condensation nuclei (CCN) (Chameides and Bergin, 2002; Menon et al., 2002). It has been reported that the contribution of soot to global warming may be second to that of $\mathrm{CO}_{2}$ (Jacobson, 2001; Moffet and Prather, 2009). Soot also poses a health risk by causing and enhancing respiratory, cardiovascular and allergic diseases (Sydbom et al., 2001). In addition, when emitted into the atmosphere, soot particles are subjected to several aging processes, including adsorption or condensation of gaseous species, coagulation with other preexisting aerosols and oxidation (Han et al., 2013a, 2013b, 2012c; Lelièvre et al., 2004; Saathoff et al., 2003; Zhang and Zhang, 2005; Zhang et al., 2008). These aging processes not only significantly affect the chemical composition of the atmosphere, but also induce modification of soot properties, such as morphology, hygroscopicity, and optical properties, thus 
influencing the climatic and health effects of soot (Peng et al., 2016; Zhang et al., 2008).

Sulfur-containing compounds are widely distributed in fuels. Sulfur in fuel can be converted to toxic sulfur oxides $\left(\mathrm{SO}_{2}\right)$ through combustion that result in air pollution and poison the oxidation catalysts in emission control systems (Stanislaus et al., 2010). Although the environmental regulations on fuels sulfur content are currently becoming more and more stringent all around the world, the sulfur content in fuels remains exceedingly high in the developing countries, such as China and Brazil (http:// www.dieselnet.com/standards/br/

fuel_automotive.php\#anp_2009, 2015; Zhang et al., 2010).

Many previous studies imply that fuel properties show a strong influence on soot properties including functional groups, morphology, and chemical composition as well as microstructure (Daly and Horn, 2009; Jansma et al., 2012; Lu et al., 2012). Therefore, sulfur-containing compounds widely distributed in fuels may affect soot properties. At present, a large number of studies have been performed on combustion of sulfur-containing fuels in diesel engines (Arnold et al., 2006, 2012; Giechaskiel et al., 2005; Jansma et al., 2012; Lu et al., 2012; Maricq et al., 2002; Olfert et al., 2007; Ronkko et al., 2013; Saiyasitpanich et al., 2005; Shi and Harrison, 1999; Weingartner et al., 1997) or diffusion flames (GÜLder and GlavinČEvski, 1991). The majority of these studies have mainly showed that sulfur in fuel promoted exhaust particle formation (Arnold et al., 2006, 2012; Ronkko et al., 2013; Shi and Harrison, 1999) or emission (Saiyasitpanich et al., 2005), especially for ultrafine particles. However, the way by which sulfur in fuel promoted particle formation or emission has been not clearly understood. Meanwhile, only a few studies pay attention to the effect of sulfur in fuel on the properties of soot (Jansma et al., 2012; Lu et al., 2012; Olfert et al., 2007; Weingartner et al., 1997). For example, little is known about the effects of sulfur in fuel on soot morphology, and no experiments have been undertaken so far to investigate the quantity of sulfate adsorbed in soot. Therefore, the influence of sulfur in fuel on soot particle properties has not been clearly understood. In this study, diffusion flame soot prepared under well-controlled combustion conditions was investigated in laboratory experiments. By combining several measurements, characteristics of soot such as functional groups, composition, morphology and hygroscopicity were analyzed as a function of the sulfur content in fuel. The results will increase understanding of the effect of sulfur in fuel on soot properties and may also help assess the environmental effects of soot.

\section{Experimental section}

\subsection{Soot production}

Soot samples were produced in a co-flow homemade burner system as described in detail in our previous studies (Han et al., 2012a, 2012b, 2013a, 2013b). The co-flow burner consisted of a diffusion flame maintained in a flow of synthetic air, which was controlled by mass flow meters to regulate the fuel/oxygen ratio. The fuel was fed by a cotton wick extending into the liquid fuel reservoir. The combustion conditions were expressed as the molar ratio of the consumed fuel (measured by the mass of consumed nhexane) to the introduced oxygen (obtained from the entrained airflow volume) during the combustion process. Thus, soot samples obtained from a relatively high fuel/oxygen ratio of about 0.16 and a relatively low fuel/oxygen ratio of about 0.12 were identified as "rich" flame soot and "lean" flame soot, respectively, as used in our previous studies (Han et al., 2013a, 2012a, 2012c).

N-hexane (AR, Sinopharm Chemical Reagent Lo., Ltd.) was used as model liquid fuel, and thiophene (AR, Sinopharm Chemical
Reagent Lo., Ltd.), a major sulfur-containing compound in fossil fuel (Dai et al., 2008), was added to n-hexane to vary the sulfur content in fuel as used in previous studies (Bladt et al., 2012; Dai et al., 2008; GÜLder and GlavinČEvski, 1991; Hernandez-Maldonado and Yang, 2003).

\subsection{Characterization of soot}

The functional groups of soot samples were characterized using a Fourier transform infrared spectrometer (FT-IR, NEXUS 6700, Thermo Nicolet Instrument Corp.) equipped with a high-sensitivity mercury-cadmium-telluride (MCT) detector cooled by liquid $\mathrm{N}_{2}$ and an ATR-IR cell. The spectra of soot were recorded (100 scans, $4 \mathrm{~cm}^{-1}$ resolution) using the blank ZnSe ATR crystal as reference in the spectral range from 4000 to $650 \mathrm{~cm}^{-1}$. Alkynes on soot were further identified using Lindlar catalyst, which can selectively catalyze conversion of alkynes to alkenes (Lindlar, 1952; Rajaram et al., 1983; Vile et al., 2014). A portion of soot generated from fuel containing 3420 ppm S was extracted in toluene by ultrasonication. The extract was hydrogenated in the presence of Lindlar catalyst according to the literature (Rajaram et al., 1983). Alkynes in the toluene extracts of soot from fuel containing $3420 \mathrm{ppm} S$ before and after reaction were characterized in an ATR-IR cell after evaporation of toluene, as described above. Elemental analysis was performed on a Vario EL Analyzer (Elementar Analysensysteme Gmbh, Hanau, Germany).

Sulfate species in soot were detected with ion chromatography (IC). A portion of soot collected on polytetrafluoroethylene membranes (PTFE, Pall corporation) was extracted in ultrapure water by ultrasonication for $30 \mathrm{~min}$ in a water bath, where ice was regularly added to avoid heating. Then, the extract was filtered through a nylon syringe filter $(0.22 \mu \mathrm{m})$. The obtained sulfate solution was analyzed with IC using a Metrohm 820 IC separation center (with a Metrosep A Supp5-150 column and an 819 IC conductivity detector). An eluent of $9.0 \mathrm{mM} \mathrm{Na}_{2} \mathrm{CO}_{3}$ was used. An auto-sampler was used where $50 \mu \mathrm{L}$ of each sample was introduced into the eluent, which was kept at a flow rate of $1.0 \mathrm{~mL} \mathrm{~min}^{-1}$. Meanwhile, the presence of ammonium ion $\left(\mathrm{NH}_{4}^{+}\right)$in soot was also examined with IC.

Gaseous sulfur, mainly $\mathrm{SO}_{2}$, was examined with IC. The exhaust gas containing $\mathrm{SO}_{2}$ filtered through a PTFE membrane was directly bubbled into an adsorption solution containing excessive sodium hydroxide, and $\mathrm{SO}_{2}$ was adsorbed as sulfite. Then, a large amount of ozone $\left(\mathrm{O}_{3}\right)$ was bubbled into adsorption solution, through which sulfite was transformed to sulfate. The obtained sulfate solution was analyzed with IC as mentioned above.

The morphology and particle size of the soot were examined using a TEM (H-7500, Hitachi). Soot produced in a diffusion flame was directly deposited onto a $\mathrm{Cu}$ microgrid. The acceleration voltage was set to $80 \mathrm{kV}$ for the measurements. Image J $1.41 \mathrm{soft}-$ ware was used to analyze the diameter of primary soot particles.

The particle number concentration and size distribution of lean flame soot were measured with a scanning mobility particle sizer (SMPS, TSI Model 3081) equipped with DMA 3080 (TSI Inc.) and CPC 3776 (TSI Inc.). An electrical Low Pressure Impactor (ELPI, Dekati Inc.) was used to control the stability of the particle emission during the SMPS scans. Before passing through the SMPS, the exhaust gas was diluted by zero air, and the dilution ratio was 7.5. The length of the sampling line from the diluter to the particle instruments was minimized. Each experiment was repeated five times and the results were found to agree with each other within the $95 \%$ confidence level.

The hygroscopicity of soot was investigated qualitatively using ATR-IR. Fresh lean flame soot particles were directly deposited on the ZnSe crystal of the ATR-IR cell, which was then sealed with a 
Teflon cover and flushed with dry $\mathrm{N}_{2}$. The spectra of samples were recorded during water evaporation until the spectrum showed no obvious change, suggesting that the dehydration process was complete. Then, $\mathrm{N}_{2}$ with controlled humidity was introduced, and the spectra of soot were recorded with the dehydrated soot surface taken as the reference background spectrum (100 scans, $4 \mathrm{~cm}^{-1}$ resolution). The relative humidity $(\mathrm{RH})$ was recorded by a moisture meter (CENTER 314, China) and controlled by changing the mixture ratio of dry $\mathrm{N}_{2}$ and humid $\mathrm{N}_{2}$.

The water content of soot samples was measured quantitatively on a Quantachrome Autosorb-1-C instrument equipped with a vapor generator, which has been described elsewhere in detail (Ma et al., 2010b, 2013a). The water adsorption capacity was measured based on the conventional volumetric method. Prior to the water uptake experiments, fresh soot samples were outgassed at $3.0 \times 10^{-3}$ Torr and at room temperature for $3 \mathrm{~h}$ to remove the adsorbed water. The temperature of the sample during the water uptake experiment was held at $278.15 \pm 0.1 \mathrm{~K}$ by a super thermostat and a cryofluid pump (DFY 5/80, Henan Yuhua laboratory instrument factory).

\section{Results and discussion}

\subsection{Functional groups on soot}

Previous studies suggested that the majority of sulfur in fuel was oxidized to $\mathrm{SO}_{2}$ during combustion, and only a small percentage was converted to sulfates in particulate matter (Corro, 2002; Saiyasitpanich et al., 2005). Hence, in order to investigate the influence of a large amount of sulfur in fuel, which is as high as about 2000 ppm in some parts of the developing countries (http:// www.dieselnet.com/standards/br/

fuel_automotive.php\#anp_2009, 2015; Zhang et al., 2010), and to obtain adequate amounts of sulfur-containing species in soot to facilitate the research, the sulfur content in fuel ranged from 0 to $3420 \mathrm{ppm}$ in this study.

Fig. 1 shows the ATR-IR spectra of fresh rich flame soot and lean flame soot prepared from fuel with a variable sulfur content. The peaks and functional groups are given in Table 1. Functional groups, including the alkyne $\mathrm{C}-\mathrm{H}$ group $\left(3284 \mathrm{~cm}^{-1}\right)$, aromatic $\mathrm{C}-\mathrm{H}$ group
Table 1

IR Assignment of surface species for rich and lean flame soot; reference: ${ }^{1} \mathrm{Han}$ et al. (2012a), ${ }^{2}$ Santamaria et al. (2006), ${ }^{3}$ Kirchner et al. (2000), ${ }^{4}$ Smith and Chughtai (1995), ${ }^{5}$ Cain et al. (2010), ${ }^{6}$ Smith (1998), ${ }^{7}$ Querry et al. (1974). ${ }^{8}$ Zhang et al. (1993), ${ }^{9}$ Niki et al. (1980), ${ }^{10}$ Smith et al. (1989) and ${ }^{11}$ Kirchner et al. (2003).

\begin{tabular}{|c|c|c|}
\hline \multirow[t]{2}{*}{ Surface species } & \multicolumn{2}{|c|}{ Wave numbers $\left(\mathrm{cm}^{-1}\right)$} \\
\hline & This study & Literature \\
\hline Alkyne $\equiv \mathrm{C}-\mathrm{H}$ & 3284 & $3284,{ }^{1} 3300,,^{2} 3320^{3}$ \\
\hline Aromatic $\mathrm{C}-\mathrm{H}$ & 3040 & $3030,{ }^{2} 3040,,^{1,4} 3050^{3,5}$ \\
\hline Carbonyl $\mathrm{C}=\mathrm{O}$ & 1710 & $1710,{ }^{1} 1720^{2,3,5}$ \\
\hline $\mathrm{C}=\mathrm{O}$ bonded to an aromatic ring & 1590 & $1590,{ }^{1} 1600^{3,5}$ \\
\hline Unsaturated $\mathrm{C}-\mathrm{H}\left(=\mathrm{CH}_{2}\right)$ & 1440 & $1440,{ }^{4} 1450,,^{2} 1460^{5}$ \\
\hline $\mathrm{O}-\mathrm{H}$ in carboxylic acid & 1420 & $1418^{6}$ \\
\hline Aliphatic $\mathrm{C}-\mathrm{H}\left(\mathrm{CH}_{3}\right.$ groups $)$ & 1386 & $1380^{2}$ \\
\hline \multirow[t]{2}{*}{$\mathrm{HSO}_{4}^{-}$} & 1228 & $1230^{7,8}$ \\
\hline & 1030 & $1050^{7,9}$ \\
\hline $\mathrm{H}_{2} \mathrm{SO}_{4}$ & 1180 & $1187,,^{9} 1190,,^{7} 1225-1180^{10}$ \\
\hline $\mathrm{SO}_{4}^{2-}$ & 1080 & $1104,{ }^{7,8} 1090^{11}$ \\
\hline Substituted aromatic $\mathrm{C}-\mathrm{H}$ & 876 & $876,,^{1} 880^{3-5}$ \\
\hline Substituted aromatic $\mathrm{C}-\mathrm{H}$ & 840 & $840,{ }^{1} 840^{3-5}$ \\
\hline Substituted aromatic $\mathrm{C}-\mathrm{H}$ & 745 & $745,{ }^{1} 760^{3-5}$ \\
\hline
\end{tabular}

(3040 $\left.\mathrm{cm}^{-1}\right)$, carbonyl $(\mathrm{C}=\mathrm{O})$ group bound to aromatic rings (1590 $\left.\mathrm{cm}^{-1}\right)$, unsaturated $\mathrm{C}-\mathrm{H}\left(=\mathrm{CH}_{2}\right)$ group $\left(1440 \mathrm{~cm}^{-1}\right)$ and substituted aromatic $\mathrm{C}-\mathrm{H}$ groups $\left(876 \mathrm{~cm}^{-1}, 840 \mathrm{~cm}^{-1}, 745 \mathrm{~cm}^{-1}\right)$ (Cain et al., 2010; Han et al., 2012c; Kirchner et al., 2000; Santamaria et al., 2006; Smith and Chughtai, 1995) were observed in the spectra of soot from sulfur-free fuel. This result was in good agreement with our previous study (Han et al., 2012a). Additionally, one shoulder peak at $1386 \mathrm{~cm}^{-1}$ was attributed to the aliphatic $\mathrm{C}-\mathrm{H}$ plane deformations of $\mathrm{CH}_{3}$ group (Santamaria et al., 2006) and another shoulder peak at $1420 \mathrm{~cm}^{-1}$ was related to the in-plane OH bending mode of carboxylic acid (Smith, 1998). The peak at $1710 \mathrm{~cm}^{-1}$ in the spectra of rich flame soot was assigned to the carbonyl $(C=0)$ group (Han et al., 2012a). When sulfur was added to fuel, new absorption peaks at 1228 and $1030 \mathrm{~cm}^{-1}\left(\mathrm{HSO}_{4}^{-}\right)$, $1180 \mathrm{~cm}^{-1}\left(\mathrm{H}_{2} \mathrm{SO}_{4}\right), 1080 \mathrm{~cm}^{-1}\left(\mathrm{SO}_{4}^{2-}\right)$ (Kirchner et al., 2003; Niki et al., 1980; Popovicheva, 2004; Querry et al., 1974; Smith et al., 1989; Zhang et al., 1993) (referred to as sulfate species) were found in the spectra of rich flame soot and lean flame soot, which suggested that sulfate species were generated on soot. Furthermore, because adsorption peaks at $\sim 3284$ and $\sim 1440 \mathrm{~cm}^{-1}$ may be
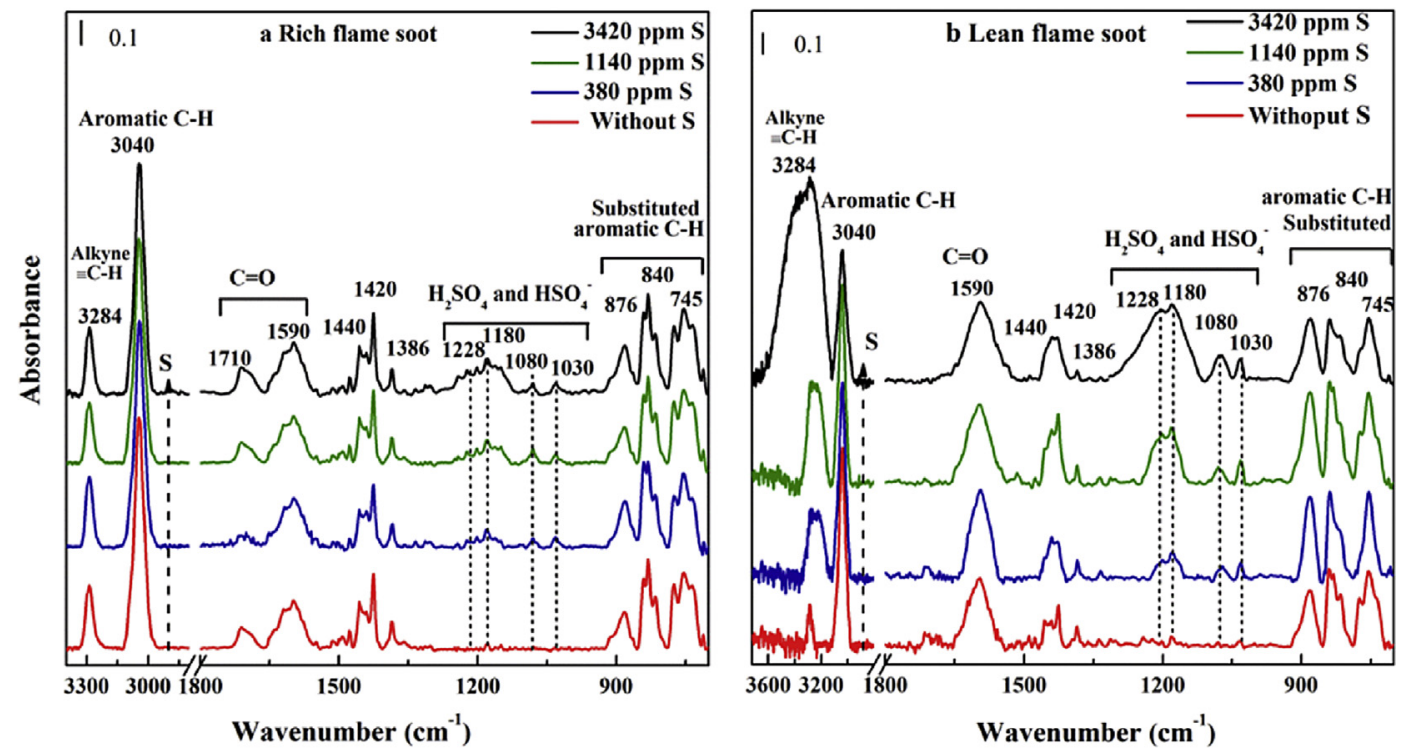

Fig. 1. Typical baseline-corrected, normalized ATR-IR spectra for fresh soot. (a) Rich flame soot. (b) Lean flame soot. 
contributed by ammonium ions (Coates, 2000), ammonium ions on lean flame soot generated from fuel containing sulfur were determined with IC. It can be observed from Fig. S1 that there were no ammonium ions present in the extract of soot from fuel containing sulfur.

Compared with rich flame soot, lean flame soot showed stronger peaks of sulfate species. The intensities of these peaks increased with the increasing of the sulfur content in fuel, implying that a lean flame was more favorable to sulfate species generation. This was because the higher oxygen content in lean flame was favorable for the conversion of sulfur in fuel into $\mathrm{SO}_{2}$ and further into sulfate species.

At the same time, for lean flame soot from fuel containing 3420 ppm S, a strong and broad absorption peak at $3284 \mathrm{~cm}^{-1}$ was observed as shown in Fig. 1b, which might be related to alkyne $\mathrm{C}-\mathrm{H}$ groups (Han et al., 2012a) or the $\mathrm{OH}$ stretching mode of a small amount of water adsorbed on soot (Lu et al., 2008b). Alkynes on soot were further identified with the use of Lindlar catalyst, which can selectively catalyze conversion of alkynes to alkenes (Lindlar, 1952; Rajaram et al., 1983; Vile et al., 2014). The ATR-IR spectra of the toluene extracts of lean flame soot from fuel containing 3420 ppm S before and after hydrogenation are shown in Fig. 2. It can be observed that the peak at $3284 \mathrm{~cm}^{-1}$ disappeared after hydrogenation. Based on the unique ability of Lindlar catalyst to selectively reduce $\mathrm{C} \equiv \mathrm{C}$ to $\mathrm{C}=\mathrm{C}$ (Vile et al., 2014), we can confirm that the strong peak at $3284 \mathrm{~cm}^{-1}$ corresponded to the alkyne $\mathrm{C}-\mathrm{H}$ stretch. This result indicates that a large amount of alkynes were formed in lean flame when the fuel contained sulfur in lean flame. Furthermore, this result provides further evidence in support of the suggestion proposed by (Smith, 1981) that $\mathrm{SO}_{2}$ and $\mathrm{SO}_{3}$ originating from sulfur in fuel can catalyze the recombination of $\mathrm{O}$ and $\mathrm{OH}$, thereby reducing the degree of acetylene oxidation and enhancing alkynes formation.

It has been known that alkynes, such as acetylene, are the main intermediates in the formation and growth of soot particles (Committee on Chemical Engineering Frontiers: Research Needs and Opportunities; Mathematics, 1988; Donnet et al., 1993). Therefore, large amounts of alkynes on lean flame soot from sulfurcontaining fuel might influence the diameter and the number concentration of soot particles. This influence was investigated in the following context.

In addition, the effect of sulfur in terms of $\mathrm{SO}_{2}$ in synthetic air on

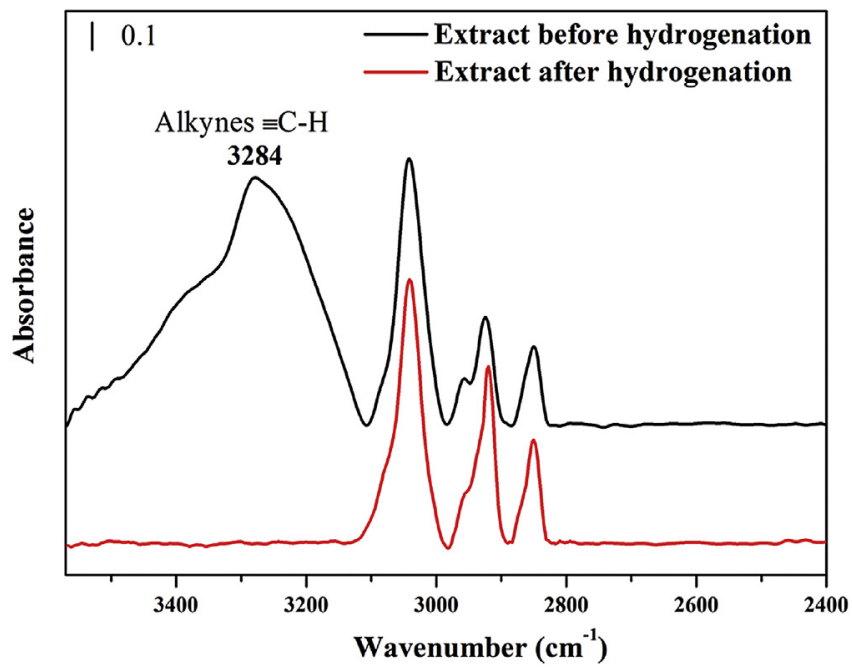

Fig. 2. Baseline-corrected, normalized ATR-IR spectra for extracts of lean flame soot from fuel containing $3420 \mathrm{ppm} S$ before and after hydrogenation. soot was investigated with ATR-IR. Fig. 3 presents the infrared spectra of soot prepared from sulfur contained in fuel and from $\mathrm{SO}_{2}$ injection in synthetic air. The amount of sulfur from $\mathrm{SO}_{2}$ in synthetic air was equivalent to that of sulfur in fuel containing 3420 ppm S. As seen in Fig. 3a and c, the infrared spectra of rich flame soot from sulfur in fuel were the same as those of rich flame soot obtained from $\mathrm{SO}_{2}$ injection in synthetic air. So were the infrared spectra of lean flame soot in Fig. $3 \mathrm{c}$ and d. This result suggests that sulfur in fuel and sulfur in synthetic air show the same effect on conversion of sulfur into sulfate species on soot. Meanwhile, by comparison, it can be found in Fig. 3a and b that more sulfate species and alkynes were formed on lean flame soot than on rich flame soot. This result indicates that the effect of sulfur in fuel on soot properties is related to the combustion conditions, while lean flame soot is influenced more by sulfur in fuel than rich flame soot. Therefore, we focused the investigation on lean flame soot properties in this study.

\subsection{Sulfur in soot}

Lean flame soot was investigated with elemental analysis to identify the chemical composition, and sulfate species in lean flame soot were analyzed with IC. The results are shown in Table 2 and Fig. 4. As seen from Table 2, all soot samples were mainly composed of carbon with a high mass fraction of about 92 wt\% (Sadezky et al., 2005), as well as low mass fractions of hydrogen (about $1 \mathrm{wt} \%$ ), oxygen (about $1.4 \mathrm{wt} \%$ ) and nitrogen (about $0.5 \mathrm{wt} \%$ ), independently of sulfur added to fuel. Sulfur was detected when lean flame soot was prepared from sulfur-containing fuel. At the same time, it can be observed in Fig. 4a that the sulfur fraction in soot increased nonlinearly as a function of the sulfur content in fuel. Similarly, the sulfate species fraction in soot also increased nonlinearly from 0 to $3.2 \mathrm{mg}$ per gram of soot as the sulfur content in fuel increased in the range of $0-3420 \mathrm{ppm}$, as shown in Fig. $4 \mathrm{~b}$.

Fig. 4c shows the amount of sulfate species formed on the surface of soot as a function of the sulfur content in fuel. The amount of sulfate species was represented by the integrated absorbance of two peaks at 1128 and $1180 \mathrm{~cm}^{-1}$. The influence of soot amount deposited on the ZnSe crystal of the ATR-IR cell on the integrated absorbance was offset through dividing the integrated absorbance of the IR peaks of sulfate species by the integrated absorbance of one of the substituted aromatic $\mathrm{C}-\mathrm{H}$ group peak $\left(923-852 \mathrm{~cm}^{-1}\right)$. As seen in Fig. 4c, the integrated absorbance of sulfate species increased linearly as the sulfur content in fuel increased. This result suggests that the amount of sulfate species on the surface of soot increases linearly as a function of the sulfur content in fuel, which is not consistent with the results of elemental analysis and IC. This discrepancy may be explained by the uneven distribution of sulfur in soot. For elemental composition, sulfur both on the surface and in the bulk of soot was detected. Similarly, IC examined all sulfate species on the surface and in the bulk of soot. However, only sulfate species on the surface of soot were detected with ATR-IR. Therefore, it can be concluded that sulfate species are mainly formed on the surface of soot through coating during the processes of combustion and cooling.

\subsection{The distribution of sulfur in fuel among combustion products}

The distribution of sulfur among combustion products was investigated, taking fuel containing $3420 \mathrm{ppm} \mathrm{S}$ as an example. It can be found from the results of IC that about $83 \mathrm{wt} \%$ of sulfur in fuel was converted to gaseous $\mathrm{SO}_{2}$, and $5 \mathrm{wt} \%$ appeared as sulfate species in lean flame soot. For lean flame soot investigated with the fuel/oxygen ratio of 0.12 , the corresponding equivalence ratio, which was defined as the ratio of the fuel/oxidizer ratio to the 

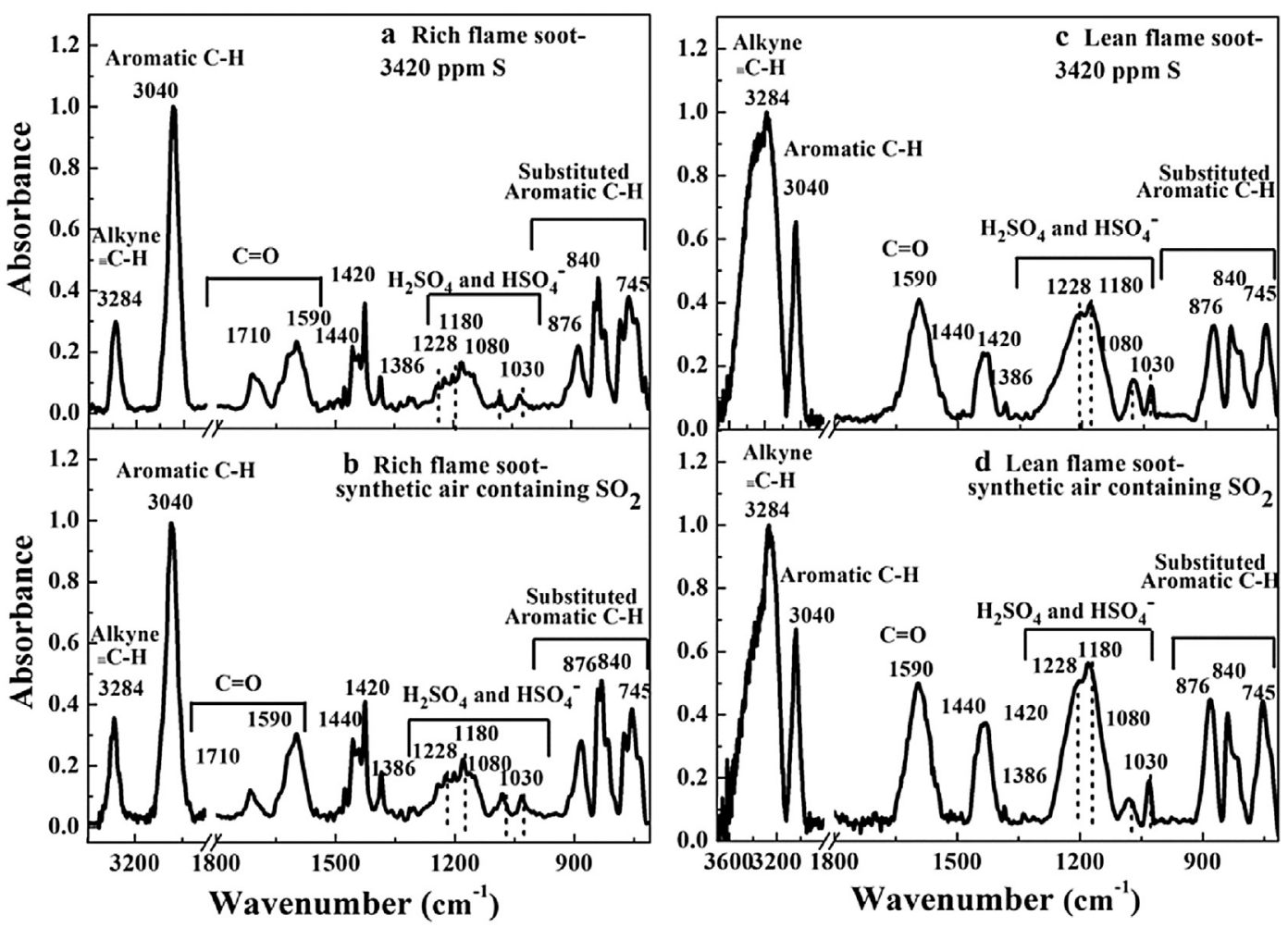

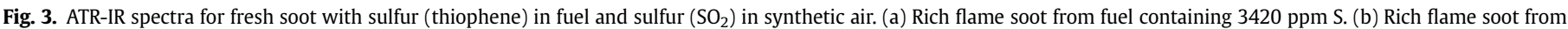
$\mathrm{SO}_{2}$ in synthetic air. (c) Lean flame soot from fuel containing $3420 \mathrm{ppm} \mathrm{S}$. (d) Lean flame soot from $\mathrm{SO}_{2}$ in synthetic air.

Table 2

Elemental composition of fresh lean flame soot samples.

\begin{tabular}{|c|c|c|c|c|c|}
\hline \multirow[t]{2}{*}{ Sulfur content in fuel (ppm) } & \multicolumn{5}{|c|}{ Elemental analysis (wt\%) } \\
\hline & C & $\mathrm{H}$ & $\mathrm{O}$ & $\mathrm{N}$ & S \\
\hline 0 & $92.54 \pm 0.54$ & $1.27 \pm 0.21$ & $1.44 \pm 0.15$ & $0.58 \pm 0.07$ & 0 \\
\hline 380 & $92.19 \pm 0.28$ & $0.94 \pm 0.04$ & $1.60 \pm 0.05$ & $0.57 \pm 0.08$ & $0.18 \pm 0.03$ \\
\hline 1140 & $92.30 \pm 0.36$ & $1.03 \pm 0.38$ & $1.33 \pm 0.03$ & $0.51 \pm 0.08$ & $0.25 \pm 0.03$ \\
\hline 3420 & $92.44 \pm 0.15$ & $1.13 \pm 0.37$ & $1.56 \pm 0.03$ & $0.53 \pm 0.05$ & $0.43 \pm 0.04$ \\
\hline
\end{tabular}

stoichiometric fuel/oxidizer ratio, was 1.10 as shown in Supporting Information. In this case, fuel was not completely combusted to $\mathrm{CO}_{2}$ and $\mathrm{H}_{2} \mathrm{O}$, and sulfur in fuel was also incompletely combusted. The XPS analysis confirmed thiophene-bound sulfur in soot as shown in Fig. S2. Therefore, the rest of sulfur in fuel, approximately $12 \mathrm{wt} \%$, was attributed to thiophene-bound sulfur. The sulfur distribution in the diffusion flame in this study was in good agreement with the results of engine studies showing that the majority of sulfur in fuel was converted to $\mathrm{SO}_{2}$, and only a small percentage showed up as sulfate species in particulate matter (Corro, 2002; Saiyasitpanich et al., 2005).

\subsection{Morphology of soot}

TEM measurements (Chandler et al., 2007; Han et al., 2012a; Liu et al., 2010; Park et al., 2004) and the conventional mass-size approach with application of the differential mobility analyzer (DMA) and aerosol particle mass analyzer (APM) (Pagels et al., 2009; Park et al., 2004; Xue et al., 2009) are well-established methods to characterize the morphology of soot. For the TEM measurements, the fractal dimension of agglomerates $\left(D_{f}\right)$, a parameter widely used to describe the compactness of the population of agglomerates (Pagels et al., 2009), is determined through extracting 3D structural properties from measured 2D projected images. In this process, uncertainties occur. $\mathrm{D}_{\mathrm{f}}$ is calculated according to the following empirical and statistical relationships in the TEM measurements (Hu et al., 2003; Park et al., 2004):

$N \cong\left(\mathrm{d}_{\mathrm{a}} / \overline{\mathrm{d}}_{\mathrm{p}}\right)^{2 \alpha} \cong\left(L / \overline{\mathrm{d}}_{\mathrm{p}}\right)^{\mathrm{D}_{\mathrm{f}}}$

where $\mathrm{N}$ is the number of primary particles in an aggregated sample, $d_{a}=\left(4 A_{a} / \pi\right)^{1 / 2}$ is the area-equivalent diameter of the measured aggregated projected area $\left(A_{a}\right), \alpha=1.09$ is an empirical parameter to account for the particles screening on projected TEM images, and $\mathrm{L}$ is the measured maximum aggregate length. For the conventional mass-size approach, $D_{f}$ is determined based on the mobility diameter and mass of the same agglomerate particles. It has been suggested that $D_{f}$ measured by TEM for diesel particles is in reasonable agreement with that by DMA-APM (Park et al., 2004). In addition, the diameter of primary soot particles $\left(d_{p}\right)$ can be obtained from TEM images. Therefore, TEM measurements were applied to determine the morphology of soot aggregates and the diameter of primary particles as used previously (Han et al., 2012a; Liu et al., 2010). All properties parameters, including the ratio of maximum length (L) to average width of aggregates $(\mathrm{W})$, the fractal 


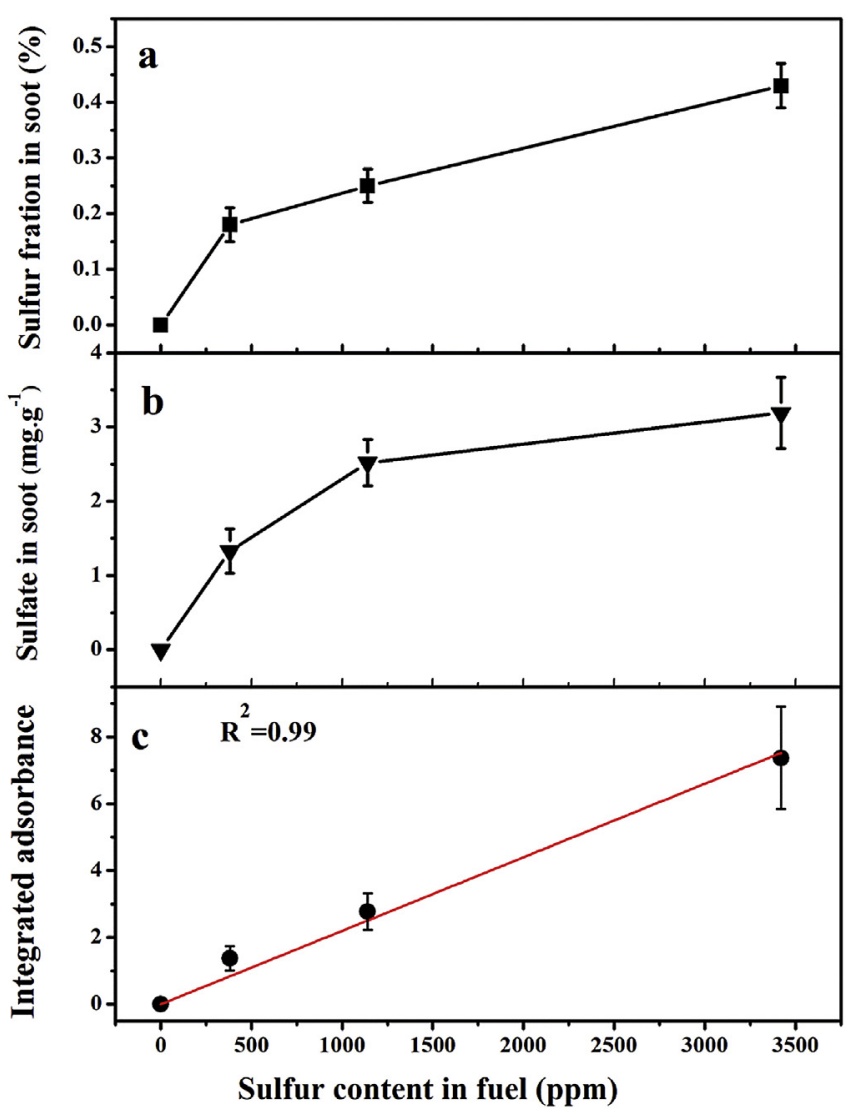

Fig. 4. (a) Sulfur fraction in lean flame soot measured with elemental analysis. (b) Sulfate species fraction in lean flame soot measured with Ion Chromatography. (c) The amount of sulfate species on the surface of lean flame soot measured with ATR-IR. The amount of sulfate species was represented by integrated absorbance of two peaks at 1228 and $1180 \mathrm{~cm}^{-1}$ between 1324 and $1116 \mathrm{~cm}^{-1}$.

dimension of agglomerates $\left(\mathrm{D}_{\mathrm{f}}\right)$ and the diameter of primary particles $\left(d_{p}\right)$, are obtained from at least 60 individual soot aggregates, to ensure that the uncertainties in the extraction of 3D structural properties from measured 2D projected images are as low as possible. Error bars show the standard deviation of over 60 individual soot aggregates.

Fig. 5 shows TEM images of fresh lean flame soot samples generated from sulfur-free fuel (Fig. 5a) and fuel containing 3420 ppm S (Fig. 5b). Both kinds of soot samples presented chainlike agglomerates composed of typical spherical particles as reported in other studies (Qiu et al., 2012; Zhang et al., 2008).

As seen in Table 3, for both kinds of lean flame soot from sulfurfree fuel and sulfur-containing fuel, the ratios of maximum length (L) to average width of aggregates $(\mathrm{W})$ were around 6 , which was close to the value of $n$-hexane flame soot reported by Han et al. (2012a). Fig. 6 shows the diameter distribution of primary soot particles. The proportion of spherical particles with large diameter $(>35 \mathrm{~nm})$ for lean flame soot from sulfur-containing fuel was significantly greater than that of soot from sulfur-free fuel, while the opposite was observed for small particles $(<35 \mathrm{~nm})$. Correspondingly, the average diameter $\left(\overline{\mathrm{d}}_{\mathrm{p}}\right)$ of primary soot particles significantly increased from $35.49 \pm 7.60 \mathrm{~nm}$ (for sulfur-free fuel) to $39.66 \pm 6.42 \mathrm{~nm}$ (for sulfur-containing fuel) as shown in Table 3 . However, no significant changes in the diameter of primary particles were observed when the sulfur content in fuel was varied in an engine study (Lu et al., 2012). This lack of change in $\bar{d}_{p}$ may be mainly related to the sulfur content in fuel being less than $500 \mathrm{ppm}$.
Smith (1981) suggested that $\mathrm{SO}_{2}$ and $\mathrm{SO}_{3}$ originating from sulfur in fuel can catalyze the recombination of $\mathrm{O}$ and $\mathrm{OH}$, thereby reducing the degree of acetylene oxidation. In our study, the higher intensity of the alkyne $\mathrm{C}-\mathrm{H}$ stretching band observed in the ATR-IR spectra in Fig. 1b for lean flame soot from fuel containing 3420 ppm S indicated more alkynes were formed. Alkynes are the main intermediates in the formation and growth of soot particles as mentioned above. Hence, the diameter of primary soot particles might increase as a result of an abundant amount of alkynes being formed when fuel contained $3420 \mathrm{ppm} \mathrm{S}$. The sulfur content in fuel was less than 500 ppm reported by Lu et al. (2012), thereby without enough amount of alkynes to promote the significant growth of primary particles. Therefore, it can be implied that a high content of sulfur in fuel influences the combustion process of the fuel in lean flame, thus causing more alkynes formation and increasing the diameter of primary soot particles.

The $D_{f}$ for these two kinds of soot particles maintained the same value of 1.63 , which closely agreed with that (1.7) of propane flame soot (Slowik et al., 2004). However, Olfert et al. (2007) observed a drastic increase in the fractal dimension of the particles with a large fraction of sulfate species in the particulate matter at high engine loads. The high engine loads and a diesel oxidation catalyst (DOC) fitted on the engine may have contributed to this increase. Higher loads increased the concentration of $\mathrm{SO}_{2}$ available for the formation of sulfate species by enhancing the fuel consumption (Giechaskiel et al., 2005). Meanwhile, the DOC converted more $\mathrm{SO}_{2}$ to $\mathrm{SO}_{3}$ at higher DOC temperatures when operating at high engine loads (Maricq et al., 2002). Hence, during the process of cooling, increased amounts of sulfate species were formed and condensed on the soot agglomerates, which filled in the voids of the particles, thus making the particles more compact and increasing the fractal dimension. Sulfate species and water accounted for up to $29 \mathrm{wt} \%$ of the total particulate matter with the sulfur content in fuel of less than $50 \mathrm{ppm}$ at high loads and in the presence of DOC in the study of Olfert et al. (2007). However, the sulfate species fraction in lean flame soot particulates was only about $0.3 \mathrm{wt} \%$ with the sulfur content in fuel of $3420 \mathrm{ppm}$ as shown in Fig. 4b in this study. Therefore, it can be implied that the effect of sulfur in fuel on soot properties is closely related to combustion conditions.

\subsection{The size distribution and particle number concentration}

The size distribution and particle number concentration of lean flame soot were measured with an SMPS. Fig. 7 presents the size distributions of lean flame soot particles from sulfur-free fuel and fuel containing $3420 \mathrm{ppm}$ S. For lean flame soot from sulfur-free fuel, the particle size distributions only showed the accumulation mode with the geometric mean diameter (GMD) of $190 \mathrm{~nm}$. However, the particle size distributions displayed both the nucleation mode (GMD $20 \mathrm{~nm}$ ) and the accumulation mode (GMD $190 \mathrm{~nm}$ ) for lean flame soot from sulfur-containing fuel. The smaller nucleation mode particles detected in the latter were mainly caused by nucleation of sulfate species originating from sulfur in fuel as reported in a diesel engine study (Schneider et al., 2005). The larger accumulation mode particles were mainly composed of soot agglomerates, and they presented a similar size distribution for both kinds of soot. Meanwhile, the particle number concentrations of the accumulation mode particles were calculated according to the SMPS measurement. The accumulation mode particle number concentrations of soot from sulfur-containing fuel slightly increased, with an increase degree of $4 \%$ compared with those of sulfur-free fuel as shown in Fig. 7, implying that the accumulation mode particle nucleation was enhanced as a result of more alkynes being formed, as described above in section 3.1. Combined with the increased diameter of primary particles observed in section 3.4, it 

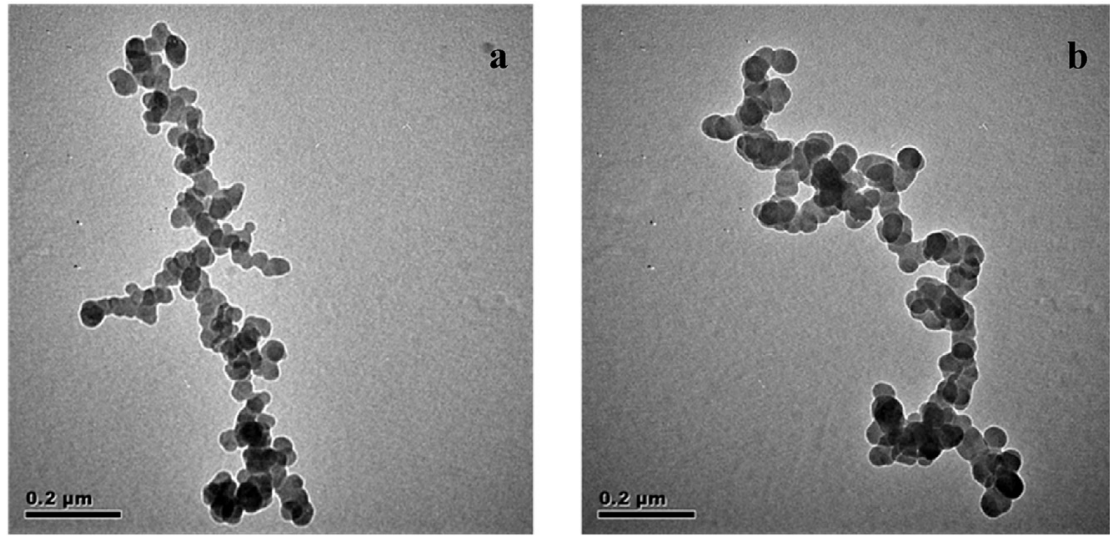

Fig. 5. TEM images of fresh lean flame soot. (a) Without S. (b) $3420 \mathrm{ppm} \mathrm{S.}$

Table 3

Ratio of maximum length (L) to average width of aggregates (W) and average diameter of primary particles $\left(\bar{d}_{p}\right)$ and the fractal dimension $\left(D_{f}\right)$ of fresh lean flame soot.

\begin{tabular}{llll}
\hline Sulfur content in fuel $(\mathrm{ppm})$ & $L / W$ & $\overline{\mathrm{d}}_{\mathrm{p}}(\mathrm{nm})$ & $D_{f}$ \\
\hline 3420 & $6.78 \pm 1.56$ & $39.66 \pm 6.42$ & $1.63 \pm 0.06$ \\
0 & $5.90 \pm 2.06$ & $35.49 \pm 7.60$ & $1.63 \pm 0.06$ \\
\hline
\end{tabular}

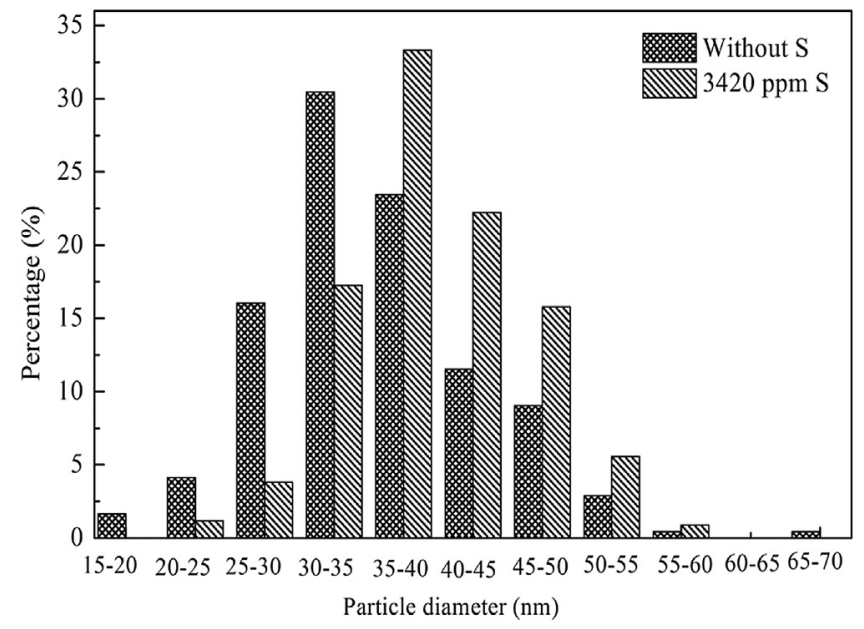

Fig. 6. Diameter distribution of primary lean flame soot particles.

can be suggested that the diameter of primary soot particles was increased and the accumulation mode particle number concentrations of lean flame soot was promoted as a result of more alkynes being formed.

\subsection{Water uptake and hygroscopicity of soot}

Both the hygroscopicity tandem differential mobility analyzer (HTDMA) (Henning et al., 2012; Khalizov et al., 2009; Qiu et al., 2014; Zhang et al., 2008) and ATR-IR spectroscopy (Lu et al., 2008a, 2008b; Wang et al., 2008; Zhang et al., 2014) are widely used to characterize the hygroscopicity of particles. Using ATR-IR spectroscopy, the hygroscopicity of the bulk soot aggregates deposited on the ZnSe substrate is examined by observing the changes in the IR band of adsorbed water. For HTDMA, the hygroscopicity of the single suspended soot particles is obtained by observing the changes in the measured particle sizes. A previous study has found that the hygroscopicities measured by HTDMA for Suwannee River fulvic acid (SRFA) and humic acid sodium salt (NaHA) are supported by ATR-IR absorption measurements (Hatch et al., 2009). However, both of these methods have their own advantages and disadvantages. For example, the detailed structural information on water molecules adsorbed on particles can be obtained in ATR-IR, while the substrate may have an influence on the measurement of the hygroscopicity. For HTDMA, although suspended particles can be measured, a certain shrinking of soot aggregates simultaneously accompanying the uptake of water on soot may have a negative influence on their hygroscopicity measurement. Up to now, the hygroscopicity of soot particles coated by sulfate species has been well studied using HTDMA (Zhang et al., 2008). Here, ATR-IR spectroscopy was firstly applied to qualitatively examine the water uptake and the hygroscopicity of soot.

Fig. 8 shows the ATR-IR spectra of lean flame soot at various RHs using soot dehydrated by $\mathrm{N}_{2}$ as reference. Three peaks at $\sim 3500$, $\sim 3426$ and $\sim 3149 \mathrm{~cm}^{-1}$ assigned to the $\mathrm{O}-\mathrm{H}$ stretching mode of water and one peak at $\sim 1635 \mathrm{~cm}^{-1}$ related to the bending mode of water (Lu et al., 2008b; Ma et al., 2010a) were observed in the ATRIR spectra of soot from fuel containing $3420 \mathrm{ppm} \mathrm{S}$ at various RHs as shown in Fig. 8a. All four of these peaks increased in intensity with an increase in $\mathrm{RH}$, but the peak at $\sim 3426 \mathrm{~cm}^{-1}$ increased faster than the other two $\mathrm{O}-\mathrm{H}$ stretching mode peaks. According to the study

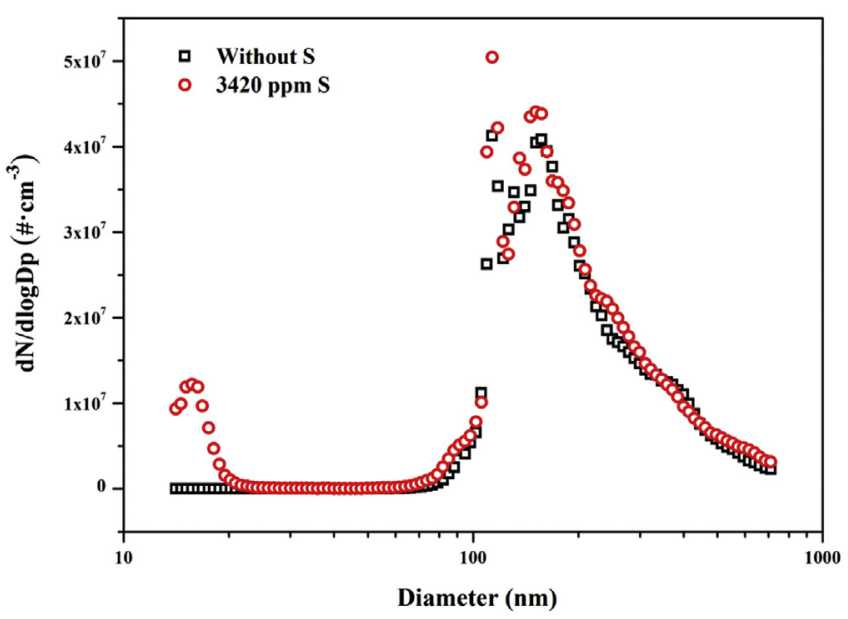

Fig. 7. Particle number and size distributions measured with SMPS. The total number concentration of soot particle from fuel containing $3420 \mathrm{ppm} \mathrm{S}$ is $9.92 \times 10^{8} \mathrm{~cm}^{-3}$ with the accumulation mode particle number concentrations of $9.76 \times 10^{8} \mathrm{~cm}^{-3}$. The total number concentration of soot particle from sulfur-free fuel is $9.15 \times 10^{8} \mathrm{~cm}^{-3}$. 
of Lu et al. (2008b), we suggested that the peak at $~ 3500 \mathrm{~cm}^{-1}$ was contributed by water monomers adsorbed on the surface of soot, while the peaks at $\sim 3426$ and $\sim 3129 \mathrm{~cm}^{-1}$ were due to aggregated water molecules on soot. Thus, the adsorption and aggregation processes of water molecules on soot as RH increases are clearly presented in Fig. 8a. As observed in Fig. 8a, there were prominent losses of intensities for bands at $1420 \mathrm{~cm}^{-1}$ (carboxylic acid $\mathrm{OH}$ ) (Smith, 1998), 1180 and $1030 \mathrm{~cm}^{-1}$ (sulfate species) (Niki et al., 1980; Querry et al., 1974), accompanied with increased intensities of the peaks of water when RH increased. The gradual loss in the intensities of these polar functional groups may be caused by increasing amounts of water adsorbed on them as RH increased. Therefore, this result suggests that polar functional groups are the main active sites for water adsorption on soot. As shown in Fig. 8b, adsorption peaks of water in ATR-IR spectra of soot from sulfur-free fuel at various RHs were much weaker when compared with those of soot from sulfur-containing fuel. This implies that less water was adsorbed on the soot from sulfur-free fuel.

Furthermore, the integrated intensities of water adsorption peaks in the $2700-3720 \mathrm{~cm}^{-1}$ range on two kinds of soot are shown in Fig. 9. Both isotherms represented a typical type-III adsorption curve as reported for most soot samples (Chughtai et al., 1999), indicating that the adsorption of water on these two kinds of soot was cooperative. Additionally, it was obvious that the water adsorption isotherm for fresh lean flame soot from sulfurcontaining fuel was higher than that for soot from sulfur-free fuel. This result suggests that sulfur in fuel increases the hygroscopicity of lean flame soot for sulfate species formed during combustion act as active sites for water adsorption.

The water adsorption behaviors of fresh lean flame soot from sulfur-free fuel and fuel containing 3420 ppm S are shown in Fig. 10. The water adsorption isotherms for both kinds of soot samples resembled those of the qualitative adsorption isotherms shown in Fig. 9, indicating that ATR-IR spectroscopy was a feasible method for qualitatively analyzing the hygroscopicity of soot particles. Based on the surface area of soot samples (48.10 and $40.88 \mathrm{~m}^{2} \mathrm{~g}^{-1}$ for sulfur-free fuel and sulfur-containing fuel, respectively) and a reasonable assumption about the molecular area of the adsorbed water $\left(12.2 \AA^{2}\right.$ ) (Chughtai et al., 1996), the mass of water adsorbed on soot was converted into coverage in terms of formal water monolayers. As seen in Fig. 10, for soot from sulfur-containing fuel, more than two monolayers of water molecules were adsorbed at $90 \% \mathrm{RH}$. However, the amount of water molecules adsorbed on soot from sulfur-free fuel was less than one monolayer even at $90 \% \mathrm{RH}$. This result indicates that water adsorbed on soot is significantly increased when fuel contains sulfur. As shown in Figs. S3 and S4 and Table S1, the surface area and pore volume of all fresh soot samples were similar. Therefore, it can be concluded that the enhanced hygroscopicity of lean flame soot from sulfur-containing fuel is mainly due to sulfate species on the surface of soot acting as active sites for water adsorption. This result provides further understanding on the increased hygroscopicity of soot particles from sulfur-containing fuel, as found in a previous study (Weingartner et al., 1997), and coincides well with previous results reporting that coating by sulfate species enhanced water adsorption on soot (Popovicheva et al., 2008, 2011; Zhang and Zhang, 2005).

\section{Conclusions and implications}

Soot samples were prepared from combustion of n-hexane. The functional groups, chemical composition, morphology and hygroscopicity of soot were investigated while the sulfur content in fuel varied. The influence of sulfur in fuel was found to relate to combustion conditions, while lean flame soot was affected more by sulfur in fuel than rich flame soot. Through analysis on the

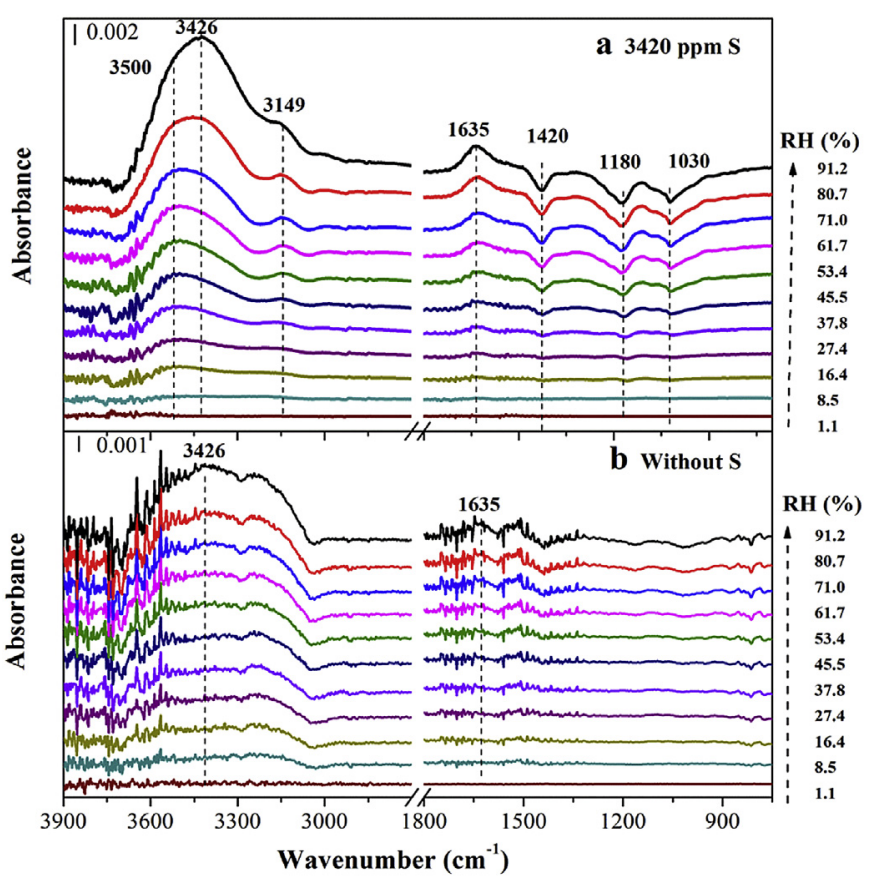

Fig. 8. ATR-IR spectra of fresh lean flame soot at various RHs. (a) 3420 ppm S. (b) Without S.

distribution of sulfur in fuel among combustion products, it was found that the majority of sulfur in fuel in lean flame was converted to gaseous $\mathrm{SO}_{2}$, and while a small fraction appeared as sulfate species in soot. Sulfate species in lean flame soot increased nonlinearly while sulfate species on the surface of lean flame soot increased linearly as the sulfur content in fuel increased. The hygroscopicity of lean flame soot was greatly enhanced for sulfate species coating on the surface of soot acted as active sites for water adsorption.

Meanwhile, a high content of sulfur in fuel influenced the combustion process of the fuel in lean flame, thus causing more alkynes formation, which increased the diameter of primary particles and enhanced the accumulation mode particle number concentrations of soot.

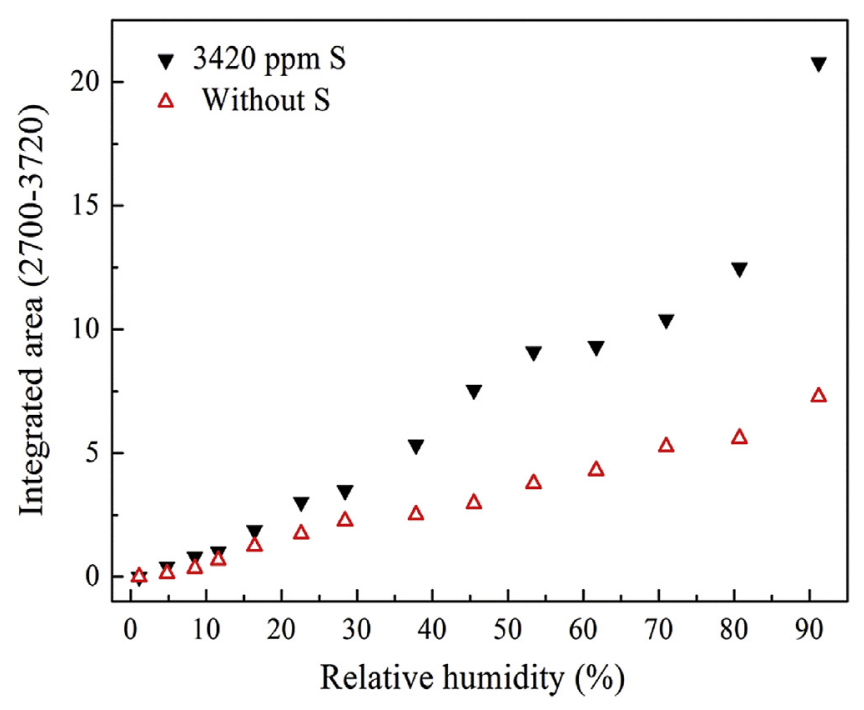

Fig. 9. Water uptake isotherms for fresh lean soot samples using ATR-IR. 


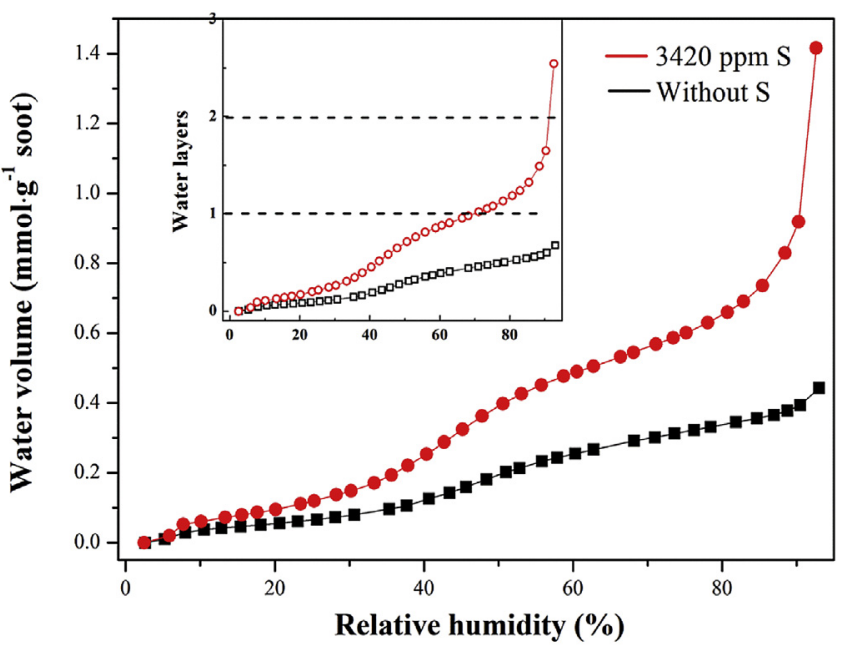

Fig. 10. Water adsorption isotherms for fresh lean flame soot samples at $278.15 \mathrm{~K}$. The insert graph shows water layers adsorbed on soot versus relative humidity.

It has been known that the potential effects of soot particles on air pollution development and climate greatly depend on the soot properties, which are related to both chemical aging and combustion conditions (Khalizov et al., 2013; Peng et al., 2016; Qiu et al., 2012, 2014; Zhang et al., 2008). The initial combustion conditions have been observed to play an important role in the hygroscopic (Han et al., 2012a) and optical properties (Qiu et al., 2014) of soot particles. In this work, we have found that fuel containing a high content of sulfur favors the formation of soot particles coated with sulfate species in lean flame. This implies that the influence that a high content of sulfur in fuel, particularly in China, exalts on soot properties may significantly affect the resulting atmospheric impacts and the further transformation of soot. Although the cloudforming potential of soot particles is mainly determined by their atmospheric aging (Khalizov et al., 2009; Ma et al., 2013b), lean flame soot particles generated from high sulfur content fuel are coated with more sulfate species, which will increase the hygroscopicity and to some extent enhance the cloud-forming potential of soot particles (Zhang et al., 2008). Sulfate species coating and the subsequently enhanced hygroscopicity of soot particles increase the light absorption and scattering of soot particles (Zhang et al., 2008), and then deteriorate the visibility and the local air quality. On the other hand, sulfate species coating during initial combustion process may reduce the lifetime of soot in the atmosphere by promoting wet deposition. This in turn partially compensates for the light adsorption and scattering of soot, which leads to a large uncertainty in estimating the climate impacts of soot (Park et al., 2011). In addition, the enhanced hygroscopicity of the soot mixture with sulfate species can create a water layer over soot, and then facilitate adsorption and reaction of other pollutants in the surrounding air, making the climate effects and relevant chemistry of soot more complicated. Therefore, this work will aid in understanding the impacts of soot particles on air quality and climate.

\section{Acknowledgments}

The research was financially supported by the Strategic Priority Research Program of the Chinese Academy of Sciences (XDB05010300).

\section{Appendix A. Supplementary data}

Supplementary data related to this article can be found at http:// dx.doi.org/10.1016/j.atmosenv.2016.08.001.

\section{References}

Arnold, F., Pirjola, L., Aufmhoff, H., Schuck, T., Lahde, T., Hameri, K., 2006. First gaseous sulfuric acid measurements in automobile exhaust: implications for volatile nanoparticle formation. Atmos. Environ. 40, 7097-7105.

Arnold, F., Pirjola, L., Ronkko, T., Reichl, U., Schlager, H., Lahde, T., Heikkila, J., Keskinen, J., 2012. First online measurements of sulfuric acid gas in modern heavy-duty diesel engine exhaust: implications for nanoparticle formation. Environ. Sci. Technol. 46, 11227-11234.

Bladt, H., Schmid, J., Kireeva, E.D., Popovicheva, O.B., Perseantseva, N.M., Timofeev, M.A., Heister, K., Uihlein, J., Ivleva, N.P., Niessner, R., 2012. Impact of Fe content in laboratory-produced soot aerosol on its composition, structure, and thermo-chemical properties. Aerosol Sci. Technol. 46, 1337-1348.

Cain, J.P., Gassman, P.L., Wang, H., Laskin, A., 2010. Micro-FTIR study of soot chemical composition-evidence of aliphatic hydrocarbons on nascent soot surfaces. Phys. Chem. Chem. Phys. 12, 5206-5218.

Chameides, W.L., Bergin, M., 2002. Soot takes center stage. Science 297, 2214-2215.

Chandler, M.F., Teng, Y., Koylu, U.O., 2007. Diesel engine particulate emissions: a comparison of mobility and microscopy size measurements. Proc. Combust. Inst. 31, 2971-2979.

Chughtai, A.R., Brooks, M.E., Smith, D.M., 1996. Hydration of black carbon. J. Geophys. Res. 101, 19505.

Chughtai, A.R., Williams, G.R., Atteya, M.M.O., Miller, N.J., Smith, D.M., 1999. Carbonaceous particle hydration. Atmos. Environ. 33, 2679-2687.

Coates, J., 2000. Interpretation of Infrared Spectra, a Practical Approach. John Wiley \& Sons Ltd, Chichester.

Committee on Chemical Engineering Frontiers: Research Needs and Opportunities; Mathematics, and Applications Commission on Physical Sciences; Division on Engineering and Physical Sciences; National Research Council, 1988. Frontiers in Chemical Engineering: Research Needs and Opportunities; National Academy Press: Washington, D.C.

Corro, G., 2002. Sulfur impact on diesel emission control- A review. React. Kinet. Catal. Lett. 75, 89-106.

Dai, W., Zhou, Y., Wang, S., Su, W., Sun, Y., Zhou, L., 2008. Desulfurization of transportation fuels targeting at removal of thiophene/benzothiophene. Fuel Process. Technol. 89, 749-755.

Daly, H.M., Horn, A.B., 2009. Heterogeneous chemistry of toluene, kerosene and diesel soots. Phys. Chem. Chem. Phys. 11, 1069-1076.

Donnet, J.-B., Bansal, R.C., Wang, M.J., 1993. Carbon Black Science and Technology. Marcel Dekker Inc, New York.

Giechaskiel, B., Ntziachristos, L., Samaras, Z., Scheer, V., Casati, R., Vogt, R., 2005. Formation potential of vehicle exhaust nucleation mode particles on-road and in the laboratory. Atmos. Environ. 39, 3191-3198.

GÜLder, Ö.L., GlavinČEvski, B., 1991. Influence of fuel-bound sulfur on soot formation in Laminar diffusion flames of liquid hydrocarbons. Combust. Sci. Technol. 77, 337-343.

Han, C., Liu, Y., Liu, C., Ma, J., He, H., 2012a. Influence of combustion conditions on hydrophilic properties and microstructure of flame soot. J. Phys. Chem. A 116, 4129-4136.

Han, C., Liu, Y., Ma, J., He, H., 2012b. Effect of soot microstructure on its ozonization reactivity. J. Chem. Phys. 137, 084507.

Han, C., Liu, Y., Ma, J., He, H., 2012c. Key role of organic carbon in the sunlightenhanced atmospheric aging of soot by 02. Proc. Natl. Acad. Sci. U. S. A. 109, 21250-21255.

Han, C., Liu, Y., He, H., 2013a. Heterogeneous photochemical aging of soot by NO2 under simulated sunlight. Atmos. Environ. 64, 270-276.

Han, C., Liu, Y., He, H., 2013b. Role of organic carbon in heterogeneous reaction of NO2 with soot. Environ. Sci. Technol. 47, 3174-3181.

Hatch, C.D., Gierlus, K.M., Zahardis, J., Schuttlefield, J., Grassian, V.H., 2009. Water uptake of humic and fulvic acid: measurements and modelling using single parameter Köhler theory. Environ. Chem. 6, 380-388.

Henning, S., Ziese, M., Kiselev, A., Saathoff, H., Möhler, O., Mentel, T.F., Buchholz, A. Spindler, C., Michaud, V., Monier, M., Sellegri, K., Stratmann, F., 2012. Hygroscopic growth and droplet activation of soot particles: uncoated, succinic or sulfuric acid coated. Atmos. Chem. Phys. 12, 4525-4537.

Hernandez-Maldonado, A.J., Yang, R.T., 2003. Desulfurization of commercial liquid fuels by selective adsorption via $\pi$-complexation with $\mathrm{Cu}(\mathrm{I})-\mathrm{Y}$ zeolite. Ind. Eng. Chem. Res. 42, 3103-3110.

http://www.dieselnet.com/standards/br/fuel_automotive.php\#anp_2009 2015.

Hu, B., Yang, B., Koylu, U.O., 2003. Soot measurements at the axis of an ethylene/air non-premixed turbulent jet flame. Combust. Flame 134, 93-106.

Jacobson, M.Z., 2001. Strong radiative heating due to the mixing state of black carbon in atmospheric aerosols. Nature 409, 695-697.

Jansma, H., Fino, D., Uitz, R., Makkee, M., 2012. Influence of diesel fuel characteristics on soot oxidation properties. Ind. Eng. Chem. Res. 51, 7559-7564.

Khalizov, A.F., Zhang, R., Zhang, D., Xue, H., Pagels, J., McMurry, P.H., 2009. Formation of highly hygroscopic soot aerosols upon internal mixing with sulfuric acid vapor. J. Geophys. Res. 114.

Khalizov, A.F., Lin, Y., Qiu, C., Guo, S., Collins, D., Zhang, R., 2013. Role of OH-initiated oxidation of isoprene in aging of combustion soot. Environ. Sci. Technol. 47, 2254-2263.

Kirchner, U., Scheer, V., Vogt, R., 2000. Ftir spectroscopic investigation of the 
mechanism and kinetics of the heterogeneous reactions of NO2 and HNO3 with soot. J. Phys. Chem. A 104, 8908-8915.

Kirchner, U., Vogt, R., Natzeck, C., Goschnick, J., 2003. Single particle MS, SNMS, SIMS, XPS, and FTIR spectroscopic analysis of soot particles during the AIDA campaign. J. Aerosol Sci. 34, 1323-1346.

Lary, D.J., Shallcross, D.E., Toumi, R., 1999. Carbonaceous aerosols and their potential role in atmospheric chemistry. J. Geophys. Res. 104, 15929-15940.

Lelièvre, S., Bedjanian, Y., Pouvesle, N., Delfau, J.-L., Vovelle, C., Le Bras, G., 2004. Heterogeneous reaction of ozone with hydrocarbon flame soot. Phys. Chem. Chem. Phys. 6, 1181-1191.

Lindlar, H., 1952. Ein neuer Katalysator fiir selektive Hydrierungen. Helv. Chim. Acta 35, 446-450.

Liu, Y., Liu, C., Ma, J., Ma, Q., He, H., 2010. Structural and hygroscopic changes of soot during heterogeneous reaction with $\mathrm{O}(3)$. Phys. Chem. Chem. Phys. 12, 10896-10903.

Lu, P.D., He, T., Zhang, Y.H., 2008a. Relative humidity anneal effect on hygroscopicity of aerosol particles studied by rapid-scan FTIR-ATR spectroscopy. Geophys. Res. Lett. 35.

Lu, P.D., Wang, F., Zhao, L.J., Li, W.X., Li, X.H., Dong, J.L., Zhang, Y.H., Lu, G.Q., 2008b. Molecular events in deliquescence and efflorescence phase transitions of sodium nitrate particles studied by Fourier transform infrared attenuated total reflection spectroscopy. J. Chem. Phys. 129, 104509.

Lu, T., Cheung, C.S., Huang, Z., 2012. Investigation on particulate oxidation from a DI diesel engine fueled with three fuels. Aerosol Sci. Technol. 46, 1349-1358.

Ma, Q., He, H., Liu, Y., 2010a. In situ DRIFTS study of hygroscopic behavior of mineral aerosol. J. Environ. Sci. 22, 555-560.

Ma, Q.X., Liu, Y.C., He, H., 2010b. The utilization of physisorption analyzer for studying the hygroscopic properties of atmospheric relevant particles. J. Phys. Chem. A 114, 4232-4237.

Ma, Q., Ma, J., Liu, C., Lai, C., He, H., 2013a. Laboratory study on the hygroscopic behavior of external and internal $\mathrm{C} 2-\mathrm{C} 4$ dicarboxylic acid-NaCl mixtures. Environ. Sci. Technol. 47, 10381-10388.

Ma, Y., Brooks, S.D., Vidaurre, G., Khalizov, A.F., Wang, L., Zhang, R., 2013b. Rapid modification of cloud-nucleating ability of aerosols by biogenic emissions. Geophys. Res. Lett. 40, 6293-6297.

Maricq, M.M., Chase, R.E., Xu, N., Laing, P.M., 2002. The effects of the catalytic converter and fuel sulfur level on motor vehicle particulate matter Emissions: light duty diesel vehicles. Environ. Sci. Technol. 36, 283-289.

Menon, S., Hansen, J., Nazarenko, L., Luo, Y., 2002. Climate effects of black carbon aerosols in China and India. Science 297, 2250-2253.

Moffet, R.C., Prather, K.A., 2009. In-situ measurements of the mixing state and optical properties of soot with implications for radiative forcing estimates. Proc. Natl. Acad. Sci. U. S. A. 106, 11872-11877.

Niki, H., Maker, P.D., Savage, C.M., Breitenbach, L.P., 1980. Fourier transform infrared study of the hydroxyl radical initiated oxidation of sulfur dioxide. J. Phys. Chem. $84,14-16$.

Olfert, J.S., Symonds, J.P.R., Collings, N., 2007. The effective density and fractal dimension of particles emitted from a light-duty diesel vehicle with a diesel oxidation catalyst. J. Aerosol Sci. 38, 69-82.

Pagels, J., Khalizov, A.F., McMurry, P.H., Zhang, R.Y., 2009. Processing of soot by controlled sulphuric acid and water Condensation-Mass and mobility relationship. Aerosol Sci. Technol. 43, 629-640.

Park, K., Kittelson, D.B., McMurry, P.H., 2004. Structural properties of diesel exhaust particles measured by transmission electron microscopy (TEM): relationships to particle mass and mobility. Aerosol Sci. Technol. 38, 881-889.

Park, S.H., Gong, S.L., Bouchet, V.S., Gong, W., Makar, P.A., Moran, M.D., Stroud, C.A., Zhang, J., 2011. Effects of black carbon aging on air quality predictions and direct radiative forcing estimation. Tellus B 63, 1026-1039.

Peng, J., Hu, M., Guo, S., Du, Z., Zheng, J., Shang, D., Zamorab, M.L., Zeng, L., Shao, M., Wu, Y.-S., Zheng, J., Wang, Y., Glen, C.R., Collins, D.R., Molina, M.J., Renyi, Z., 2016. Markedly enhanced absorption and direct radiative forcing of black carbon under polluted urban environments. Proc. Natl. Acad. Sci. U. S. A. 113, 4266-4271.

Popovicheva, O.B., 2004. Aircraft engine soot as contrail nuclei. Geophys. Res. Lett. 31.

Popovicheva, O.B., Persiantseva, N.M., Tishkova, V., Shonija, N.K., Zubareva, N.A., 2008. Quantification of water uptake by soot particles. Environ. Res. Lett. 3, 025009.

Popovicheva, O.B., Persiantseva, N.M., Kireeva, E.D., Khokhlova, T.D., Shonija, N.K., 2011. Quantification of the hygroscopic effect of soot aging in the atmosphere laboratory simulations. J. Phys. Chem. A 115, 298-306.

Qiu, C., Khalizov, A.F., Zhang, R., 2012. Soot aging from OH-initiated oxidation of toluene. Environ. Sci. Technol. 46, 9464-9472.
Qiu, C., Khalizov, A.F., Hogan, B., Petersen, E.L., Zhang, R., 2014. High sensitivity of diesel soot morphological and optical properties to combustion temperature in a shock tube. Environ. Sci. Technol. 48, 6444-6452.

Querry, M.R., Waring, R.C., Holland, W.E., Earls, L.M., Herrman, M.D., Nijm, W.P., Hale, G.M., 1974. Optical constants in the infrared for K2SO4, NH4H2PO4, and H2SO4 in water. J. Opt. Soc. Am. 64, 39-46.

Rajaram, J., Narula, A.P.S., Chawla, H.P.S., DeV, S., 1983. Semihydrogenation of acetylene-modified Lindlar catalyst. Tetrahedron 39, 2315-2322.

Ronkko, T., Lahde, T., Heikkila, J., Pirjola, L., Bauschke, U., Arnold, F., Schlager, H., Rothe, D., Yli-Ojanpera, J., Keskinen, J., 2013. Effects of gaseous sulphuric acid on diesel exhaust nanoparticle formation and characteristics. Environ. Sci. Technol. 47, 11882-11889.

Saathoff, H., Naumann, K.H., Schnaiter, M., Schöck, W., Möhler, O., Schurath, U. Weingartner, E., Gysel, M., Baltensperger, U., 2003. Coating of soot and (NH4) $2 \mathrm{SO} 4$ particles by ozonolysis products of $\alpha$-pinene. J. Aerosol Sci. 34, 1297-1321.

Sadezky, A., Muckenhuber, H., Grothe, H., Niessner, R., Pöschl, U., 2005. Raman microspectroscopy of soot and related carbonaceous materials: spectral analysis and structural information. Carbon 43, 1731-1742.

Saiyasitpanich, P., Lu, M.M., Keener, T.C., Liang, F.Y., Khang, S.J., 2005. The effect of diesel fuel sulfur content on particulate matter emissions for a nonroad diesel generator. J. Air Waste Manag. Assoc. 55, 993-998.

Santamaria, A., Mondragon, F., Molina, A., Marsh, N., Eddings, E., Sarofim, A., 2006. FT-IR and $1 \mathrm{H}$ NMR characterization of the products of an ethylene inverse diffusion flame. Combust. Flame 146, 52-62.

Schneider, J., Hock, N., Weimer, S., Borrmann, S., Kirchner, U., Vogt, R., Scheer, V., 2005. Nucleation particles in diesel Exhaust: composition inferred from in situ mass spectrometric analysis. Environ. Sci. Technol. 39, 6153-6161.

Shi, J.P., Harrison, R.M., 1999. Investigation of ultrafine particle formation during diesel exhaust dilution. Environ. Sci. Technol. 33, 3730-3736.

Slowik, J.G., Stainken, K., Davidovits, P., Williams, L.R., Jayne, J.T., Kolb, C.E., Worsnop, D.R., Rudich, Y., DeCarlo, P.F., Jimenez, J.L., 2004. Particle morphology and density characterization by combined mobility and aerodynamic diameter measurements. Part 2: application to combustion-generated soot aerosols as a function of fuel equivalence ratio. Aerosol Sci. Technol. 38, 1206-1222.

Smith, O.I., 1981. Fundamentals of soot formation in flames with application to diesel engine particulate emissions. Prog. Energy Combust. Sci. 7, 275-291.

Smith, B.C., 1998. Infrared Spectral Interpretation: a Systematic Approach. The Chemical Rubber Company Press, Florida.

Smith, D.M., Chughtai, A.R., 1995. The surface structure and reactivity of black carbon. Coll. Surf. A Physicochem. Eng. Asp. 105, 47-77.

Smith, D.M., Keifer, J.R., Novicky, M., Chughtai, A.R., 1989. An FT-IR study of the effect of simulated solar radiation and various particulates on the oxidation of SO2. Appl. Spectrosc. 43, 103-107.

Stanislaus, A., Marafi, A., Rana, M.S., 2010. Recent advances in the science and technology of ultra low sulfur diesel (ULSD) production. Catal. Today 153, 1-68.

Sydbom, A., Blomberg, A., Parnia, S., Stenfors, N., Sandstrom, T., Dahlen, S.E., 2001. Health effects of diesel exhaust emissions. Eur. Respir. J. 17, 733-746.

Vile, G., Almora-Barrios, N., Mitchell, S., Lopez, N., Perez-Ramirez, J., 2014. From the Lindlar catalyst to supported ligand-modified palladium nanoparticles: selectivity patterns and accessibility constraints in the continuous-flow three-phase hydrogenation of acetylenic compounds. Chem. Eur. J. 20, 5926-5937.

Wang, L.Y., Ding, F., Zhang, Y.H., Zhao, L.J., Hu, Y.A., 2008. Anomalous hygroscopic growth of fine particles of MgSO4 aerosols investigated by FTIR/ATR spectroscopy. Spectrochim. Acta Part A 71, 682-687.

Weingartner, E., Burtscher, H., Baltensperger, U., 1997. Hygroscopic properties of carbon and diesel soot particles. Atmos. Environ. 31, 2311-2327.

Xue, H., Khalizov, A.F., Wang, L., Zheng, J., Zhang, R., 2009. Effects of dicarboxylic acid coating on the optical properties of soot. Phys. Chem. Chem. Phys. 11, 7869-7875.

Zhang, D., Zhang, R., 2005. Laboratory investigation of heterogeneous interaction of sulfuric acid with soot. Environ. Sci. Technol. 39, 5722-5728.

Zhang, R., Wooldridge, P.J., Abbatt, J.P.D., Molina, M.J., 1993. Physical chemistry of the sulfuric acid/water binary system at low temperatures: stratospheric implications. J. Phys. Chem. 97, 7351-7358.

Zhang, R., Khalizov, A.F., Pagels, J., Zhang, D., Xue, H., McMurry, P.H., 2008. Variability in morphology, hygroscopicity, and optical properties of soot aerosols during atmospheric processing. Proc. Natl. Acad. Sci. U. S. A. 105, 10291-10296.

Zhang, K.S., Hu, J.N., Gao, S.Z., Liu, Y.A., Huang, X.J., Bao, X.F., 2010. Sulfur content of gasoline and diesel fuels in northern China. Energy Policy 38, 2934-2940.

Zhang, Q.N., Zhang, Y., Cai, C., Guo, Y.C., Reid, J.P., Zhang, Y.H., 2014. In situ observation on the dynamic process of evaporation and crystallization of sodium nitrate droplets on a ZnSe substrate by FTIR-ATR. J. Phys. Chem. A 118, 2728-2737. 